\title{
REVERSE ENGINEERING IN MODELING OF AIRCRAFT PROPELLER BLADE - FIRST STEP TO PRODUCT OPTIMIZATION
}

\author{
MUhaMmad YASIR ANWAR ${ }^{1}$, SHAHID IKRAMUllah ${ }^{2}$, FARRUKH MAZHAR ${ }^{3}$ \\ Design and Manufacturing Department, \\ School of Mechanical and Manufacturing Engineering, \\ National University of Sciences and Technology (NUST),H-12 Islamabad, Pakistan. \\ ${ }^{1}$ legions_magic@ymail.com, 2drshahid@smme.nust.edu.pk, ${ }^{3}$ farrukh-cae@nust.edu.pk
}

ABSTRACT: Propeller aircrafts have had many ups and downs throughout their use in the aviation history. Due to the current economic recession and price hikes in fuels, propeller aircrafts may yet again be a choice for aerial transport and has thus re-emerged as an active area for research. On modern propeller aircrafts old aluminum propellers are being replaced with fiber reinforced composite propellers. However, owing to their reliability, strength, and integrity, aluminum propellers are still used in military aircrafts. One of the challenges that engineers of these aircraft-type have had to deal with is the non-availability of engineering drawings of these propellers. It is practically impossible to carry out any study, research or modification on such propellers in the absence of correct CAD data. This article proposes a methodology wherein a CAD model of a C130 aircraft propeller blade can be constructed using reverse engineering techniques. Such a model would help in future aerodynamic as well as structural analyses which includes investigation on structural integrity and the fluid dynamics characteristics of propeller blades. Different steps involved in this process are discussed; starting from laser scanning to obtain the cloud of points data and subsequently generating a CAD model in a commercial CAD software. The model is then imported into an analysis software where quality surface meshes are generated using tetrahedral elements. The purpose is to prepare a meshed model for future computational analysis including CFD (Computational Fluid Dynamics) and FE (Finite Element) analysis.

ABSTRAK: Pesawat bebaling mempunyai tempoh pasang surutnya sepanjang penggunaanya dalam sejarah penerbangan. Kini disebabkan oleh kemelesetan ekonomi dan kenaikan harga minyak, pesawat bebaling mungkin akan merupakan pengangkutan udara pilihan dan seterusnya muncul semula sebagai ruangan aktif penyelidikan. Pada pesawat bebaling moden, bebaling aluminium yang lama digantikan dengan bebaling komposit yang diperkuatkan gentian. Namun, disebabkan oleh keupayaan, kekuatan dan integritinya, bebaling aluminium masih diguna pakai bagi pesawat tentera. Salah satu cabaran jurutera bagi pesawat jenis ini, adalah apabila berhadapan dengan tidak adanya lukisan kejuruteraan bagi bebaling ini. Agak mustahil untuk menjalankan sebarang ujian, kajian atau modifkasi terhadap bebaling jenis ini kerana tidak adanya data yang tepat daripada Reka Bentuk Berbantukan Komputer (CAD). Artikel ini mencadangkan metodologi di mana model Reka Bentuk Berbantukan Komputer (CAD) bagi kipas bebaling pesawat $\mathrm{C}-130$ boleh dibina menggunakan teknik kejuruteraan balikan. Model sebegini akan bakal dapat membantu bidang aerodinamik di masa hadapan. Begitu juga dengan analisis struktur yang melibatkan penyelidikan terhadap integriti struktur dan ciri-ciri dinamik bendalir kipas bebaling. Beberapa proses berbeza diperbincangkan; bermula dengan imbasan laser untuk memperolehi poin kumpulan data dan seterusnya menjanakan model Reka Bentuk Berbantukan Komputer (CAD) dengan menggunakan pengaturcara komersil. Model kemudiannya diimport ke dalam pengaturcara analisis di 
mana jejaring permukaan dijanakan dengan menggunakan unsur tetrahedron. Ini bertujuan bagi menyediakan model jejaring untuk analisis berkomputer di masa hadapan, termasuklah analisis CFD (Gambar Rajah Aliran Kawalan) dan FE (Unsur Terhingga).

KEYWORDS: reverse engineering; cloud data; laser scanning; CAD modeling; propeller blade

\section{INTRODUCTION}

\subsection{Motivation}

Over the past three decades, jet propulsion has surpassed propellers in terms of speed and performance. Until very recently, owing to the recent economic recession, fuel hikes, and advancement in propeller propulsion technology, propeller aircrafts have reemerged as a potent choice for aerial transport. This resurgence has made aircraft propellers an emerging active research area.

Currently, conventional aluminum propellers on modern aircrafts are being replaced with fiber reinforced composite propellers. However aluminum propellers are still used, especially in military aircrafts due to its reliability, strength, integrity, and above all mature technological development. Unfortunately, these old propellers do not have documented engineering design and construction data which can aid in the development of a CAD model. Hence it is practically impossible to conduct any studies for design analysis, modification, and improvement.

A large number of aircrafts in use today, especially in the developing world, were designed and built over 50 years ago. These aircrafts, though structurally aged, are still being maintained and used safely today. Due to the cost of replacement, vis-à-vis proven design, high reliability, and various other factors, such airborne platforms would foreseeably be used well beyond their intended design life span, for many decades to come.

The safe upkeep of these air vehicles demands definite measures and modification approaches to be adopted to maintain the components are in reliable and good working condition throughout their life cycle. Development of extensive inspection packages, repair, and overhauling schemes are a must to preserving these assets. In propeller aircrafts, the propeller is a vital component that is subjected to a very high spectrum of mechanical fatigue and aerodynamic loads [1].

Propeller aircrafts have gone through various phases of highs and lows as regards to usage and acceptability since their inception in the aviation industry. A 1987 Washington Post article [2] clearly foresaw the future of propeller aircrafts. To a few this may seem incomprehensible: why would the old, sluggish, and noisy propeller technology be preferred over the modern jet propulsion systems, which furthermore is supreme in terms of performance, speed, and altitude [3]. It took a few more years for the world to acknowledge that propeller aircrafts are the cheapest means of air transport for short haul operations. These aircrafts are more efficient at low and modest flight speeds when compared to turbofan propulsion [4].

The first generation of propeller driven aircraft had blades made from natural composite, i.e. wood - in Dec, 1903 history was made when the Wright brothers took off at Kitty Hawk with their wooden propeller-driven aircraft [5]. They discovered that a twisted wing can be used to convert shaft power into propulsive thrust [6]. After World War II, the wood construction was mostly replaced with aluminium alloys which provide an edge where higher thrust force, durability, and strength were required. With advancements in processing technologies and newer materials in the mid of 1960s, many researchers began 
to look for better alternatives. Dowty Inc. [7] during this period began working on the designing and manufacturing of glass and carbon fibre polymer composite propeller blades. This concept was initially implemented on a hovercraft and was then later applied on an aircraft [1]. A case example is the replacement of old metallic propellers on a C-130 aircraft with composite propeller fan blades [8]. In the late 1970's and early 1980's, escalating fuel prices motivated the development of propeller fan blades. However, in late 1980 's with the introduction of the regional jet, the development of the propeller aircraft was once again limited. However, with the current economic pressure building up, propellers yet again seem to offer its role in providing cheap commute [9]. There still exists a need to study the propellers to deliver efficient performance, have greater strength and durability, and develop lighter designs to meet ever growing air transport requirements.

As other technologies, propeller technology has also undergone development over time; there have been significant technology enhancements, which include more types of construction materials available, increased options of selecting analysis tools, along with alternative manufacturing methods, in the initial design phase. Today, conventional propeller blades are mostly being replaced with newer ones that have better design and materials; which not only provide improved cruise performance but also offer reduced weight and extended life [9]. To incorporate these propeller replacements and associated modifications on an entire transport fleet, however, requires a lot of financial investment. This motivates a strong need to study propeller blades made from different materials such as aluminium alloys, and to analyse possible strategies to enhance their structural integrity through corrective and preventive actions.

An alternate approach to circumvent this problem is to adopt reverse engineering methodology to extract ample information from the product. For a propeller blade, CAD geometry provides vital structural and construction information. Accurate engineering drawings of propeller blade are also mandatory requirement to perform any computational mechanics (FEM) or fluid dynamics (CFD) analysis. At times, only 2D drawings are available from the manufacturer which are either inaccurate or lack sufficient information as mandated by modern CAD/CAM systems. Moreover, the available information can also be limited due to insufficient proprietary rights, or the CAD techniques used in designing these blades were either non-existing, and if at all used have become obsolete altogether [10].

Propeller design and analysis require a comprehensive knowledge about the propeller, their blades and associated technologies. In instances where the engineering problem is due to limited knowledge, as in the case of propeller blades, methodologies based upon the reverse engineering approach have been employed by many researchers as a means of addressing this issue. Reverse engineering is a valuable solution for extracting the CAD geometry of any physical part. This 3D CAD model can be subsequently used in performing several operations such as analysis, rapid prototyping and improving the initial design [9].

\subsection{Literature Review}

In the reverse engineering process, surface geometry reconstruction is a challenging task. It requires a significant amount of time and skill to generate an accurate surface model from the point cloud data [11]. This operation is mostly performed manually and involves frequent manual user interaction $[12,13]$. Currently, a similar geometry input format is mostly used, which consists of a list of triangular facet data, typically in STL (Stereo Lithography) file format. The STL format, although a simple and easy file structure to use, has inherent drawbacks which includes large memory requirements and significant amount of repair time. These limitations are aggravated with increase in part complexity [11]. The following paragraphs present notable contributions in this area. 
Hosni et al. [14] attempted to utilize the geometric data of the object captured by a laser based system to Rapid Prototyping using the STL format. Hamann [15] presented his method for triangulated data file reduction based on an iterative triangle removal principle. In a similar work, Chen et al. [16] introduced his model for reducing the number of triangles used in an STL file generated from a point cloud. This was done on an STL file of a human face digitized by a coordinate measuring machine (CMM). Triangles in the planar or near planar regions were removed by comparing the normal vectors of corresponding triangles. This was then followed by re-triangulation. Another approach was introduced by Veron and Leaeon [17] by assigning error zones to each point of the initial polyhedron, thereby reducing the total number of points of the polyhedral model.

In the field of automobile design and manufacturing, Singh and Singh [18] explained the modeling of an existing brake rod of a Bajaj Pulsar motorbike. Through reverse engineering, it was found that the design's safety factor is less than 1 . Hence, remodeling of the part was carried out to attain a sufficient factor of safety value. Ismail et al. [19] presented the application of reverse engineering in modeling and machining of a four stoke piston engine. Using the digitizing process to capture the point cloud data, a CAD model was created and subsequently fed into a CAM software package to develop the manufacturing codes. Finally a CMM was used to check the accuracy of the manufactured piston.

Similarly, Cheng et al. [20] also presented a technique for reverse engineering of the 1997 Honda Accord Sedan. The CAD model of the vehicle was tested under different simulated impact tests. The results were then compared with actual car impact results. The computational test of the model confirmed its validation. Mat et al. [21] presented a case study employing the reverse engineering approach which involved modeling of an automobile side mirror. This was carried out by first manually measuring it using conventional Vernier calipers. Subsequently 3D scanning was carried out and results of both approaches were compared. Benefits such as appearance in color, textures, and shape changes were discussed. It was concluded that that software-based creation provides a viable solution in terms of cost as well as time.

Hayat et al. [22] proposed the use of reverse engineering to develop a product with greater speed and at a lower cost. Modeling of an optical mouse has been accelerated with the technique of laser scanning. Hamann and Chen [23] proposed a method in which the total point data through various planar curves is reduced. Data reduction using a median filtering method was proposed by Martin et al. [24], whereby, the point clouds were subdivided into groups that were assigned to individual grids. A reverse engineering based modeling of a biological-CAD model has also been reported in [25]; whereby these models have subsequently been used for analysis and manufacturing of body parts. In this particular work, the reverse engineering technique proved to yield the best overall result compared to other methods, including STL and MEDCAD.

The selection of CAD platform for handling a scanned cloud data is another area of concern. Among the various commercial CAD platforms, CATIA offers an edge when dealing with primitive surfaces reconstruction as compared to other CAD software such as Geomagic Studio and ProE [26]. Kumar [27] proposed a reverse engineering solution to create a CAD model using CATIA software in an industrial application, where the original CAD design of products is not available. Application of reverse engineering has been successfully applied to develop a modified cream separator. Thakare and Awate [28] presented the application of reverse engineering to model the cover plate of a gear box. A CMM probe was used to collect the point cloud data which is then imported into CATIA, which then finally converts the point cloud data into a 3D model of the cover plate. 
With these cited examples, it can be concluded that the reverse engineering technique can be successfully employed when the original manufacturer data is not available or in cases where such data cannot be shared due to proprietary reasons. The technique can be used in creating CAD files when improving the design and product performance is a requirement. Different kinds of data processing techniques; from point cloud data filtering to surface generation and creation of a solid model was done using CATIA as given in references [27], [29], [30], [31], [32] and [33]. Therefore, the main CAD environment used for reverse engineering of the propeller blade in the present study was CATIA.

\section{THE APPROACH}

Varadya et al. [29] report that reverse engineering based CAD modeling provides a solution in situations where the exact model of the part does not exist. However, knowing the geometric shape and size alone does not suffice the requirements for a comprehensive engineering model development. Other parameters such as heat treatment, types of material, tolerances on the surfaces and surface finish must also be known to carry out a detailed failure analysis of the material and structure [21]. It is the extent and type of future analysis which governs the essential steps requirements for a reverse engineering problem. A simple problem may require extracting the CAD information alone, while on the other hand, a comprehensive study and analysis entail an in depth structural, material, and mechanical investigation. Such issues often confront researchers and engineers carrying out reverse engineering tasks [27]. Therefore, a typical reverse engineering problem begins with taking down physical features of an object, followed by measuring it and finally creating a surface or solid model of the same. Any further study or research depends upon the extent of information required. In this work, a similar reverse engineering technique has been used for creating a 3D CAD model of a close replica of the C-130 aircraft propeller blade. Reconstruction of the propeller blade first involves its laser scanning. The scanned data is then used for creation of a point cloud data which is subsequently used for generating the CAD model.

\section{METHODOLOGY}

As shown in Fig. 1, the methodology adopted is more or less similar to that used for other reverse engineering operations. The work first involves 3D laser scanning of one of the four propeller blades installed on a Allison T56 turboprop engine using an ATOS Laser Scanner V 6.0. There are four Allison T56 turboprop engines installed on the C-130 aircraft, shown in Fig. 2. The blade is initially prepared by removal of the attached heater and root faring, cleaning, and surface preparation. It is then scanned to generate the point cloud data. This cloud data is used to create the 3D blade CAD model using GOM and CATIA V5 software. This model is subsequently exported into a commercial FEA solver (ANSYS) for validation. Step-by-step details of the stated tasks are described in subsequent paragraphs. 


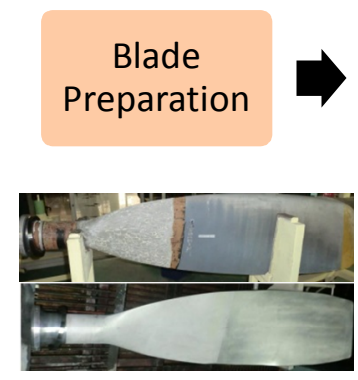

(a)

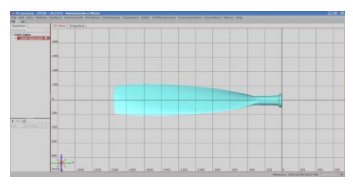

(e)

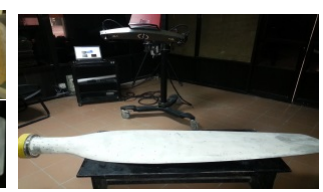

(b)

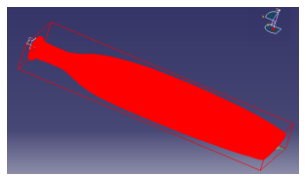

(f)

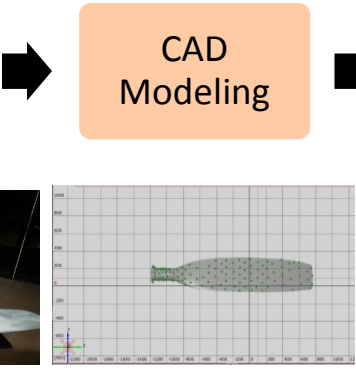

(c)

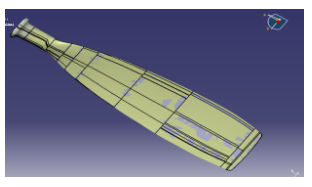

(g)

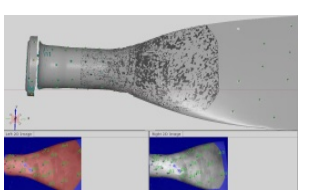

(d)

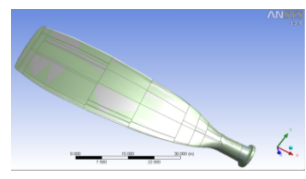

(h)

Fig. 1: Methodology adopted in modelling of Propeller Blade. (a) Preparation of the blade, (b) 3D Scanning of Blade, (c) 3D scan data processing, (d) Scan design inconsistencies, (e) 3D final clean scanned data, (f) Point cloud data in CATIA, (g) Final CAD file in CATIA, (h) Validation in ANSYS.

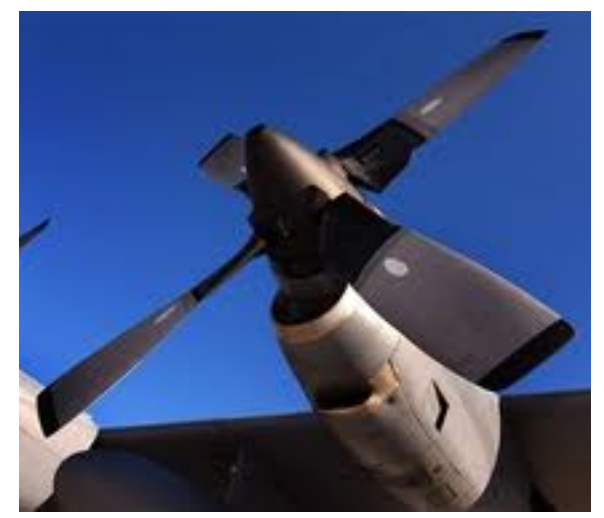

Fig. 2: Allison T56 turboprop engine with 4 propeller blades installed on C-130 aircraft.

\subsection{Blade Preparation}

The blade when disassembled from an aircraft propeller is installed with a heater and faring root area. The blade is initially prepared by removing the heater and faring of the blade carefully by using a rubber hammer as shown in the Fig. 3. A water jet system is then used for the cork and lead wool inside the shank area of the blade root. Here water at a very high pressure enters the shank portion of the blade, dissolves the wool inside it. This area is then subsequently cleaned and also prepared.

Finally, the complete blade surface is de-painted and cleaned as shown in Fig. 4. A final visual inspection of the blade is carried out to find out any abnormality or marks of damages, before the actual scanning of the blade is carried out. This was followed by dimensional analysis including thickness and diameter measurements using Vernier calliper and digital scale at blade different stations. 


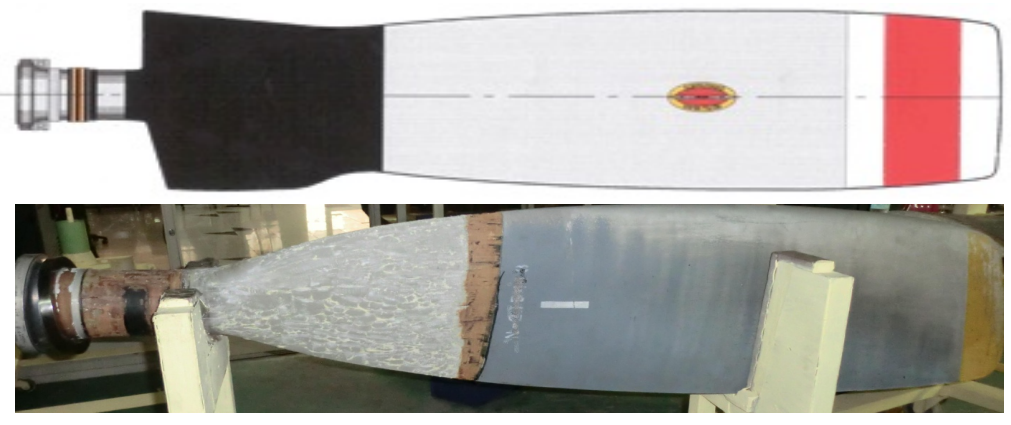

Fig. 3: Blade with faring and heater removed.

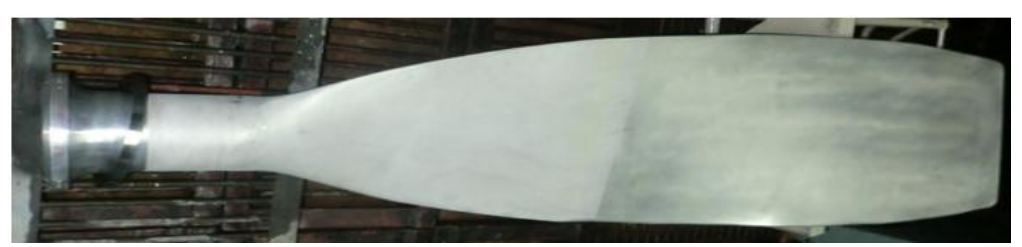

Fig. 4: Blade ready for scanning.

\subsection{Laser Scanning}

In $\mathrm{CAD}$ construction process, an efficient 3D CMM establishes a relation between the real component or model and the numerical description of the part surfaces in the computer. Using the laser based digitized system parts can be measured quickly and with high local resolution.

The scanning process is based upon the triangulation principle: the sensor unit projects different fringe patterns onto the object to be scanned which are then recorded by cameras. Each single measurement generates a set of data points. In order to digitize an object completely, several individual measurements are required from different angles. Based on reference points (circular markers), which are applied to the object directly or to the measuring plate or a fixture. The measuring data can be made available as point cloud, sections or STL data. The setup of ATOS laser scanner for blade scanning is shown in Fig. 5 [34].

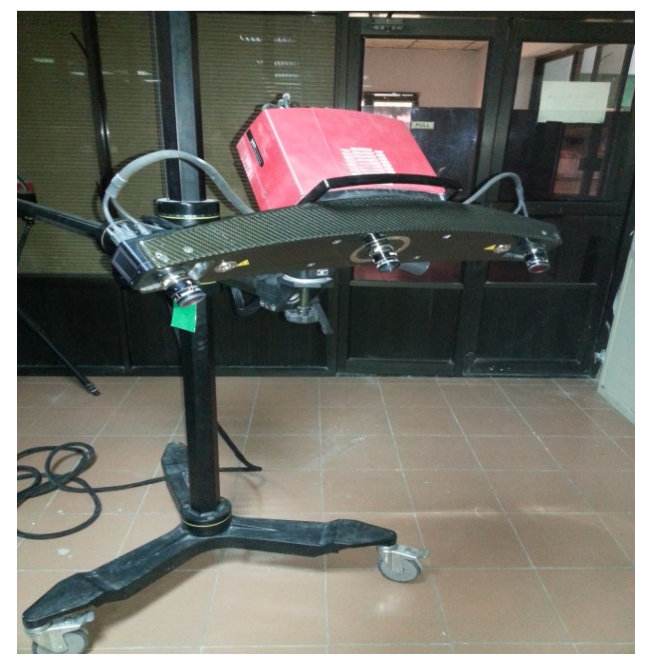

Fig. 5: ATOS Laser scanner setup. 
The blade is placed under the scanner on the table. After calibration of the scanner, up to 4 million high-precision 3D coordinate points can be digitized [34]. A number of 3D scans are taken throughout the process, for different part orientation. These scans are then assembled as shown in the Fig. 6. This may take an estimated time duration of 4 to 6 hours.
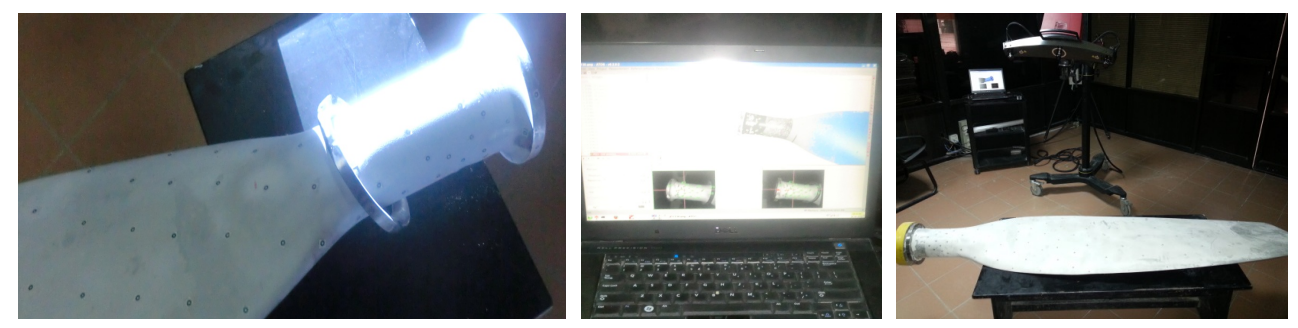

Fig. 6: Blade setup for scanning.

The GOM software provided with the scanner is used to convert the images into a final set containing complete data. This data however contains some raw points which require processing to obtain clean meshes [35]. Figure 7 indicates the steps involved in processing point cloud data to obtain a clean mesh.

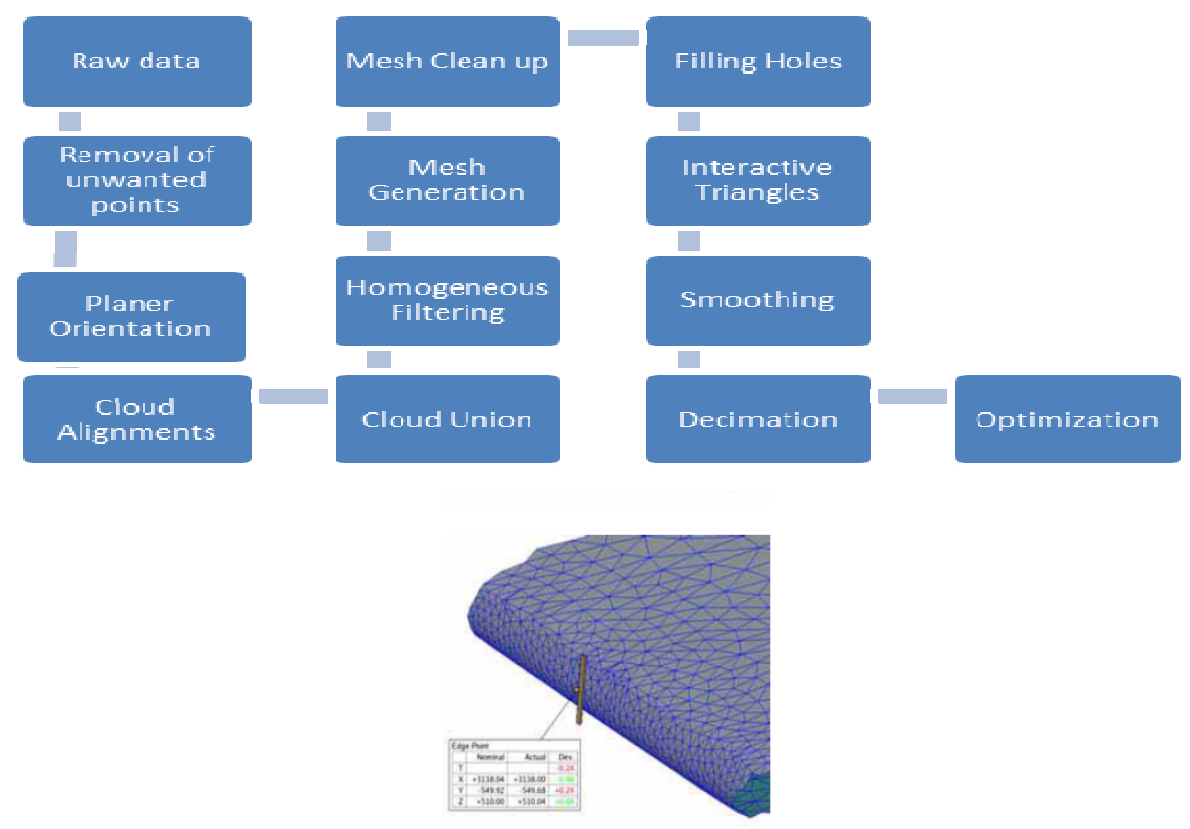

Fig. 7: Procedure to process point cloud data and obtain a clean mesh.

After complete part digitization, the measured points need to be transformed into an editable polygon mesh. During the polygonization process, the individual measurements are fine adjusted and recalculated with the highest point resolution. Overlapping areas are deleted and stitched into a polygon mesh. The point cloud data so obtained is ready to be exported into a CAD software for creation of solid surfaces. Figure 8 gives the broad representation of the process involved in the cleaning of the point scanned data 


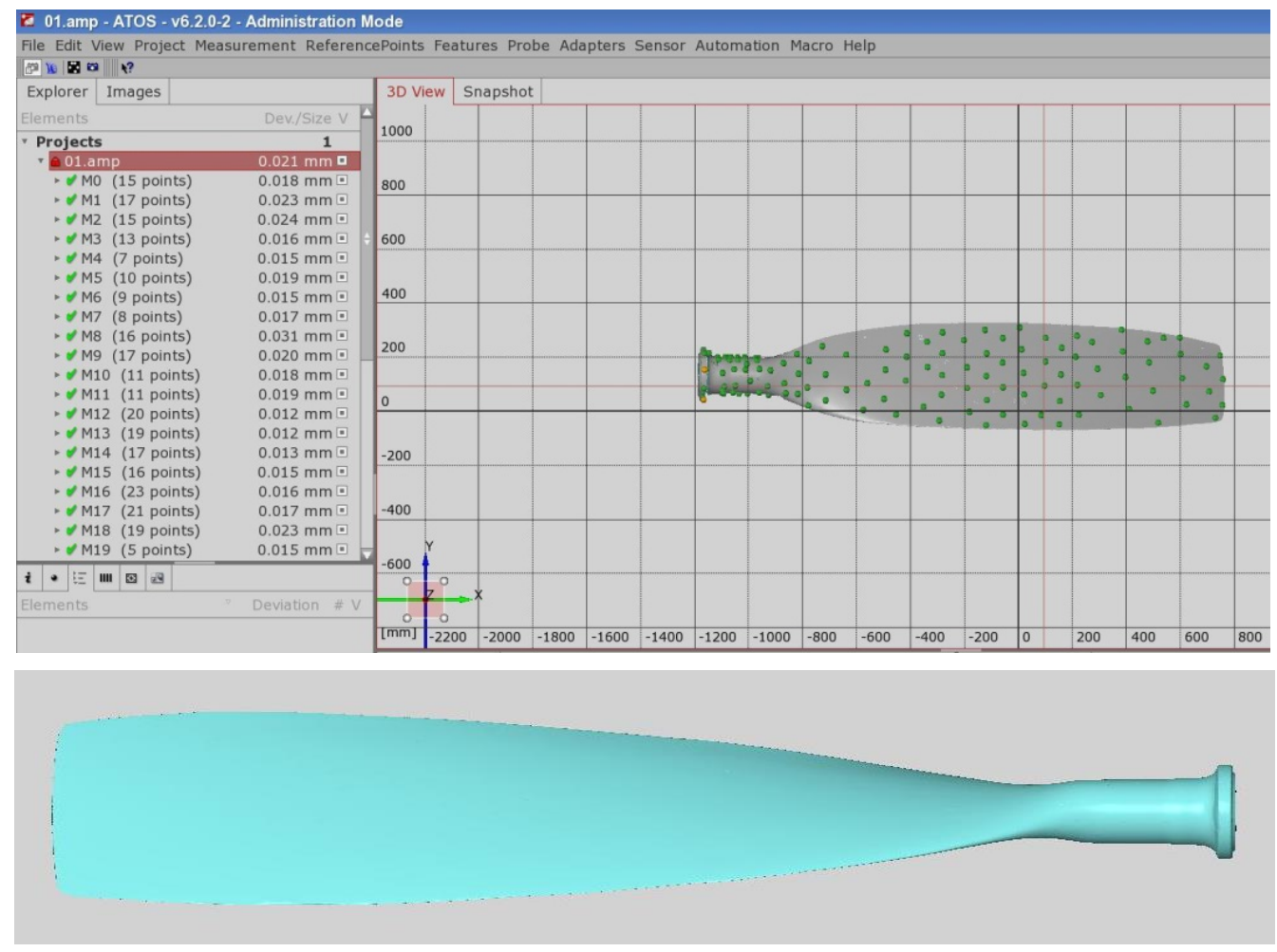

Fig. 8: 3D scanning using ATOS Scanner (GOM software). (a) 3D Scanning Raw Data, (b) Final Point Cloud data.

\subsection{Creating CAD File}

The next step is the creation of a 3D solid CAD file from the point cloud data. The scanned data file is imported into a CAD software (CATIA V5). Figure 9 describes the various stages involved in transforming the point data into a solid CAD Model.

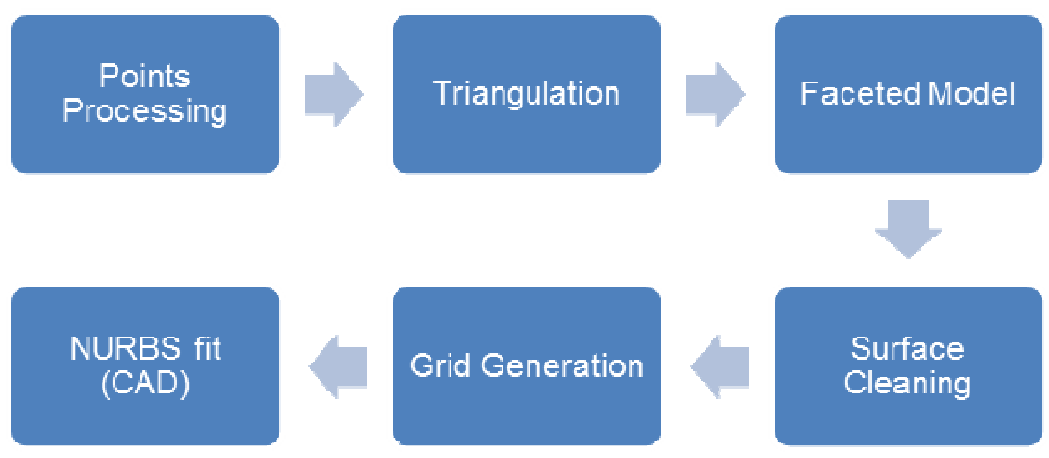

Fig. 9: Steps followed in CAD modelling.

In the first stage, the imported file is opened in the Digitized Shape Editor module of CATIA. The module is used to read, import, and process the digitized data to clouds of points. Here cleaning of the point cloud data is also carried out. The tools in the module were utilized to automatically detect and further remove any redundant and undesired points created while importing data in the software to get the digitized blade profile as shown in Fig. 10. 
The digital data can then be used in the Quick Surface Reconstruction, Digital Mockup (DMU) or Surface Machining modules, or exported into various other formats. Here meshes are created and holes and empty slots are filled. The Quick Surface Reconstruction module is used to recover surfaces from digitized data that has been cleaned up and tessellated using the Digitized Shape Editor as shown in Fig. 11. Mesh generation of the propeller blade will use an automated process of connecting the closest three points to form a triangle. This triangulation of points is repeated until the entire point cloud data is connected [36], [37].. This mesh so created, however, may still possess some irregularities which requires further cleanup. Table 1 indicates the total sizes of the nodes and elements in the model.

Table 1: Size of nodes and elements.

\begin{tabular}{ll}
\hline Entity & Size \\
\hline Nodes & 7315 \\
Elements & 3547 \\
\hline
\end{tabular}

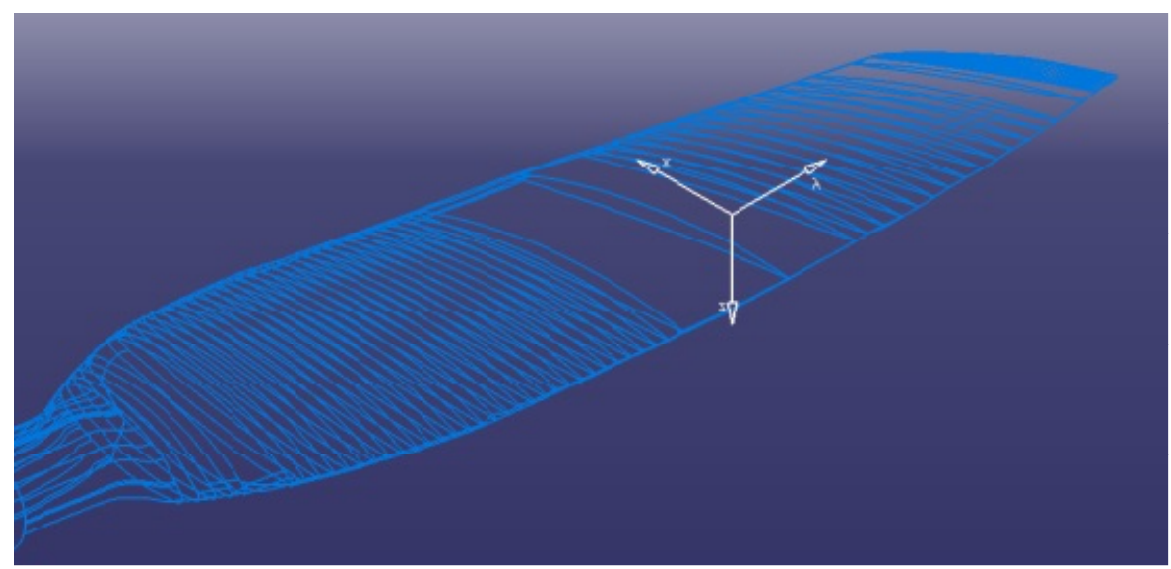

Fig. 10: Digitized shape of the blade.

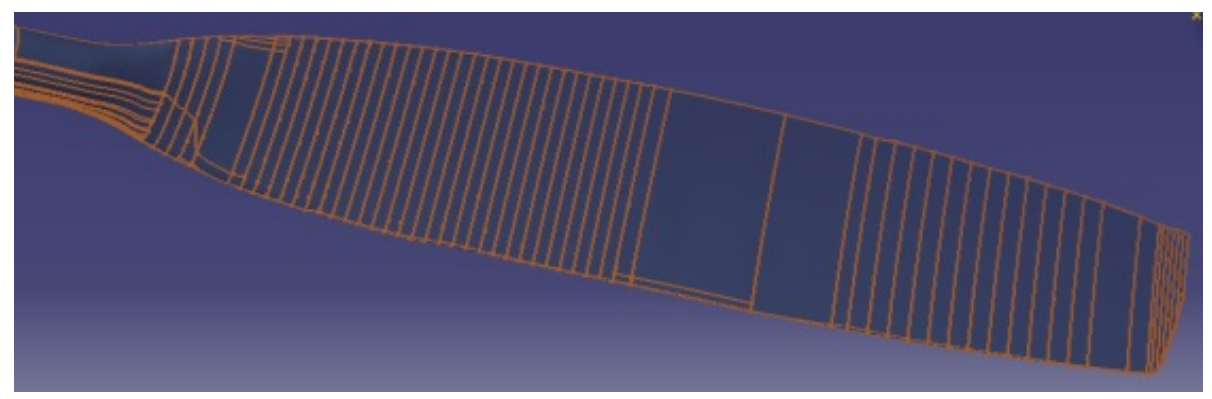

Fig. 11: Quick surface reconstruction of blade.

First, hole filling is done which is followed by smoothening to refine the mesh. Decimation and optimization steps are then performed on the propeller model to obtain the desired accuracy and to add sharpness to the clean mesh. The decimation has additional features that allows for significantly reducing the number of triangles on straight and flat surfaces and maintaining it over curvatures [35]. Figure 12 shows the meshed propeller blade. The created surfaces are then finally converted into a single volume solid and saved 
in different formats for exporting into various CAD compatible formats as shown in Fig. 13. Generally, the IGES file format is used for this purpose.

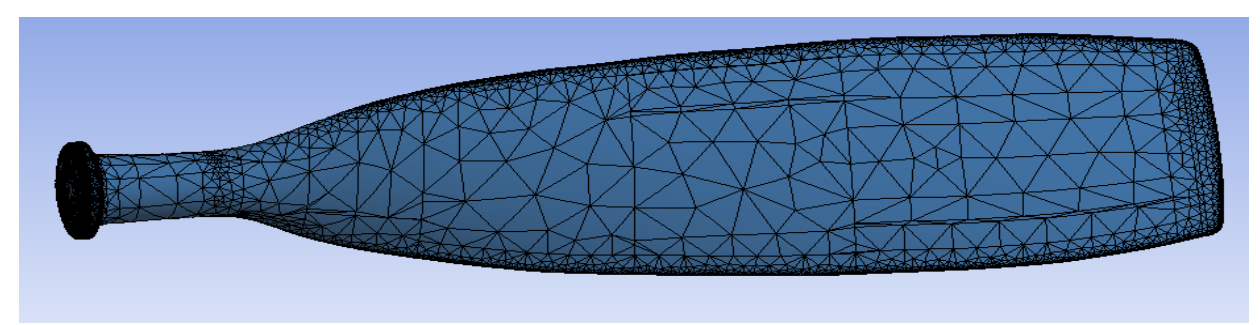

Fig. 12: Meshed propeller blade.

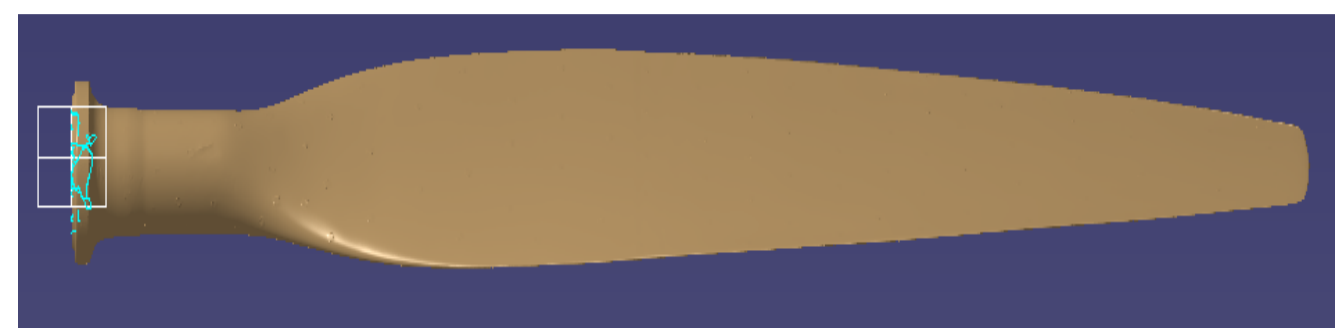

Fig. 13: Solid CAD file.

Deviation analysis of the developed CAD model is carried out from the point cloud data as shown in Fig. 14. Positive Max deviation from the point cloud data was found to be $28.55 \mathrm{~mm}$ whereas the Negative Max deviation was $-1.65 \mathrm{~mm}$.

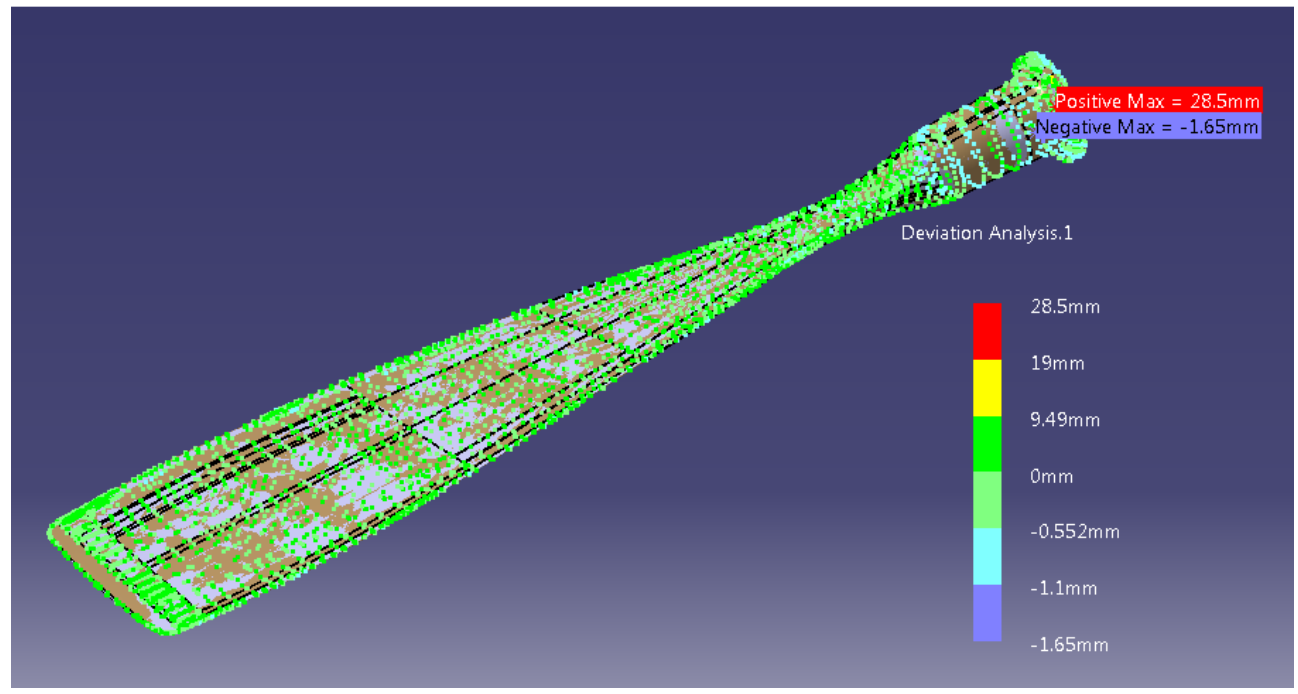

Fig. 14: Deviation Analysis of the Prop Blade CAD file from point cloud data.

\subsection{FEA Model Validation}

The IGES file obtained earlier is a solid filled CAD model of the propeller blade. This file now requires validation for correctness and future analysis. For this purpose it is exported into a finite element analysis (FEA) software ANSYS; the geometry of the FEA model is shown in Fig. 14. The blade is first meshed using free meshing (unstructured) and then mapped meshing (structured) techniques. The FEA model accuracy depends on the quality of the meshed elements [35]. The surface continuity check and meshed geometry 
of the propeller blade confirmed its validity and its capability to undergo simulated tests on structure and CFD.
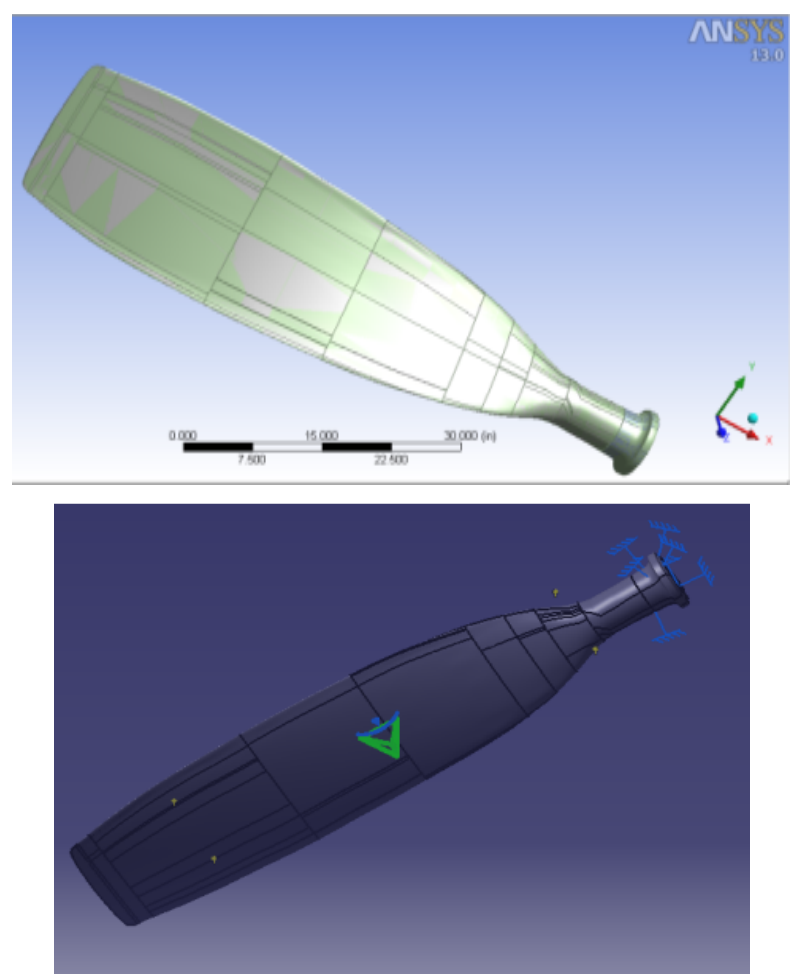

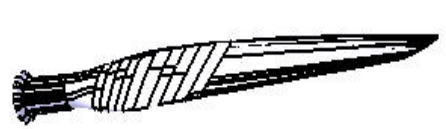

1

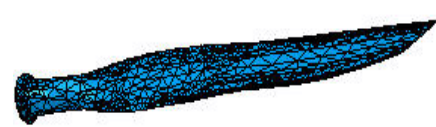

4

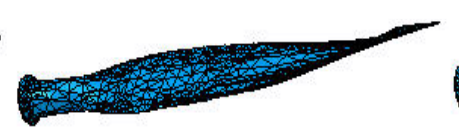

2

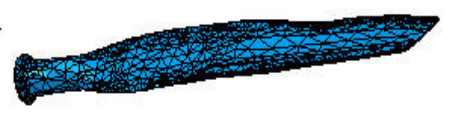

5

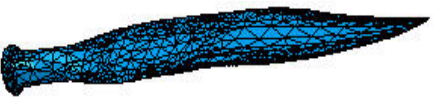

3

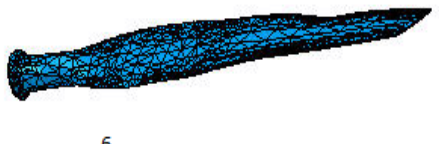

6

Fig. 15: Propeller blade in ANSYS. Blade CAD file imported in Ansys (top) and blade surface continuity check (bottom).

\section{CONCLUSION}

Application of the reverse engineering technique to carry out 3D CAD modeling of the propeller blade of a turboprop engine demonstrated a successful, cost feasible, and time saving solution. Similar techniques for CAD model generation using the laser scanner can be applied for constructing accurate geometric model for other aircraft components. In aerospace design, strict aerodynamic constraints make the curves, profile, and geometries very complex to duplicate. In all such applications 3D CAD geometry reconstruction based upon reverse engineering can provide a viable alternative.

The paper presents and discusses various necessary steps involved in a typical reverse engineering process. The work exhibits and discusses various requirements, issues, and remedies to solve associated problems by demonstrating the procedures of extracting vital 
and reliable $\mathrm{CAD}$ information from a required part. A case of reverse engineering of an aircraft propeller blade is presented for generating accurate 3D geometric construction. The need for developing a precise 3D CAD model is necessary as it is a mandatory input for accurate simulations involving computational aerodynamics as well as structural analysis.

It has been found that compatibility of files amongst different software still needs to be looked into; as importing and exporting of files among various CAD platforms at times results in significant loss of vital geometric information. Likewise, the handling of large data files is both graphically and computationally extensive in terms of memory resources. This poses a challenge to the computing machine in terms of processing time. Insufficient resources may sometimes result in system crashes and data corruption. Also, different software pose different limitations in term of handling of large point cloud data.

\section{FUTURE WORK}

In the next phase, the generated CAD model would be used for performing structural and aerodynamics analysis. The CFD analysis of the complete blade and its airfoil sections can be carried out to extract the aerodynamic load (pressure) distribution for different flight conditions. Also, the computed aerodynamic loads can be used to determine the structural strength and stiffness of the blade using FEA. A similar methodology has already been reported in literature [38]. Once the actual CAD, FEA and CFD information is extracted through detailed reverse engineering and computational analysis, additional investigation like effects of material changes, design variations can be carried out and further explored. Likewise, Modeling can be carried out through other techniques as well and the results can be compared.

\section{REFERENCES}

[1] Cantor B, Assender H, Grant P (Eds). (2010) Aerospace materials. Chapter: Advanced polymer composite propeller blades. CRC Press, USA

[2] Hamilton MM (1987) Firms Give Propellers a New Spin, Washington Post, February 8, 1987

[3] Stahr RS (1976) Oral report on the RECAT study contract at NASA, April 22, 1976, Nored papers, NASA, Lewis Research Center.

[4] Burger C (2007) Propeller performance analysis and multidisciplinary optimization using a genetic algorithm, PhD Dissertation, Auburn University, 2007

[5] Weick FE (1930) Aircraft propeller design, New York: McGraw-Hill Book Company, Inc.

[6] Anderson JD (2001) Fundamentals of Aerodynamics, 3rd ed. McGraw-Hill, New York, USA

[7] Dowty Propellers - Part of GE's Aviation Business., Company Profile. http.//www.geaviation.com/systems/products-and-services/pdf/Dowty-profile.pdf

[8] Bays L, Armor J, Wagahoff K, Halpin K (2011) Flight Test Evaluation and Aerodynamic Performance Modeling of a C-130H with an Advanced Propeller, In proceedings of 11th AIAA aviation technology, integration, and operations (ATIO) conference, 20-22 September 2011

[9] Marinus BG (2011) PhD dissertation, Ecole Centrale de Lyon, France

[10] Dorai C, Wang G, Jain AK, Mercer C (1998) Registration and Integration of Multiple Object Views for 3D Model Construction. IEEE Transactions on Pattern Analysis and Machine Intelligence 20(1):83-89

[11] Lee KH, Woo H (2000) Direct integration of reverse engineering and rapid prototyping Computers \& Industrial Engineering 38:21-38 
[12] Hoppe H (1994) Surface reconstruction from unorganized points. PhD Dissertation, University of Washington, Seattle, WA

[13] Surfacer, User's Guide, Imageware, 1997.

[14] Hosn, Y, Ferreira L, Burjanroppa R (1994) Rapid prototyping through reverse engineering, Second Industrial Engineering Research Conference Proceedings, pp 420424.

[15] Hamann B (1994) A data reduction scheme for triangulation surfaces. Computer Aided Geometric Design 11:197-214

[16] Chen YH, Ng CT, Wang YZ (1999) Data reduction in integrated reverse engineering and rapid prototyping, International Journal of Computer Integrated Manufacturing, 12(2): $97-$ 103.

[17] Véron P, Léon JC (1997) Static polyhedron simplification using error measurements. Computer Aided Design 29:287-98

[18] Singh N, Singh J (2012) Reverse engineering of brake rod of Bajaj Pulsar 150 cc motor bike using solid works and Autodesk inventor. Journal of Engineering Research and Studies, JERS/Vol. III/ Issue I/January-March, 2012/40-48: E-ISSN0976-7916

[19] Ismail AR, Soon YC, Abdullah S, Zulkifli R, Sopian K, Rahman MNA (2009) Reverse engineering in fabrication of piston crown. European Journal of Scientific Research 29(1):136-146

[20] Cheng QZ, Tackera JG, Pilkeya WD, Hollowellb WT, Reagana SW, Sievekaa EM (2001) Experiences in reverse engineering of a finite element automobile crash model, Finite Elements in Analysis and Design 37:843-860

[21] Mat S, Saedon J, Mahmud J (2009) The development of computational model through reverse engineering - side mirror case study. Journal of Mechanical Engineering and Technology 1(1): missing page.

[22] Hayat N, Anwar MY, Ajmal M, Idress A, Shah FH, Nazir S (2012) Rapid product development - A case study of ergonomically designed mouse. Pakistan Journal of Science 63(2): 108-110, 2011.

[23] Hamann B, Chen J (1994) Data point selection for piecewise linear curve approximation, Computer Aided Geometric Design 11:289-301

[24] Martin RR, Stroud IA, Marshall AD (1996) Data reduction for reverse engineering. RECCAD, Deliverable Document 1 Copernicus Project No. 1068, pp.101-113.

[25] Starly B, Fang Z, Sun W, Shokoufandeh A, Regli W (2005) Three-dimensional reconstruction for medical-CAD modeling. Computer-Aided Design \& Applications 2:431-438

[26] Martínez S, Cuestaa E, Barreiro J, Álvareza B, Fernándeza P (2008) Comparison between non-contact and contact scanning systems for dimensional control, Second International Conference on Multidisciplinary Design Optimization and Applications, 2-5 September 2008; USA

[27] Kumar V (2013) Design of cream separator machine using reverse engineering techniques. International Journal of Science and Research, 10 (2): 2319-7064

[28] Thakare SB, Awate A (2013) Reverse Engineering using CMM and CAD Tool. International Journal of Engineering Research \& Technology (IJERT) Vol.2 - Issue 10: eISSN: 2278-0181, www.ijert.org

[29] Váradya T, Martin RR, Cox J (1997) Reverse Engineering of Geometric Models - An Introduction. 29(4):255-268.

[30] Ferrise F, Bordegoni M and Cugini U (2013) Functional Modeling: A Key Point in CAD Systems. ASME 2013 International Mechanical Engineering Congress and Exposition, Vol 12: Systems and Design San Diego, California, USA, November 15-21, 2013 ,ISBN: 978-0-7918-5641-3.

[31] Feng CX, Xiao S (2000) Computer aided reverse engineering with CMM for digitization and LOM for duplication. $4^{\text {th }}$ Int. Conference on Frontier of Design and Manufacturing, Int'l Academic Press. June 2000, Beijing-China, pp. 16-18.

[32] Singh N (2012) Reverse Engineering - A general review. International Journal of Advance Engineering Research \& Studies 2(1):24-28 
[33] Bernard A (2000) Rapid product development case studies and data integration analysis. Computers in Industry 43:161-172

[34] ATOS Laser scanner operational manual.

[35] Chen D, Ravindran A, Vishwab P, Asaraf R (2011) Reverse Engineering Closely-Spaced Free-Form Shapes for a Fabric-over-Body Model, Scientific Research Journal of Engineering 3:1022-1029

[36] Gibson D (2004) Parametric feature recognition and surface construction from digital point cloud scans of mechanical parts, Thesis, University of Oklahoma, Norman, OK

[37] Waterma P (2004) 3D Data at work. Desktop Engineering 9(11):18-23.

[38] Mazhar F, Khan AM, Chaudhry IA, Ahsan M (2013) On using neural networks in UAV structural design for CFD data fitting and classification, Aerospace Science and Technology 30:210-225 